\title{
Posterior pituitary tumours: patient outcomes and determinants of disease recurrence or persistence
}

\author{
Liza Das ${ }^{1}$, Kim Vaiphei ${ }^{2}$, Ashutosh Rai ${ }^{3}$, Chirag Kamal Ahuja ${ }^{4}$, Paramjeet Singh ${ }^{4}$, Ishani Mohapatra ${ }^{5}$, \\ Rajesh Chhabra ${ }^{6}$, Anil Bhansalii ${ }^{1}$ Bishan Dass Radotra ${ }^{2}$, Ashley B Grossman ${ }^{7,8}$, Márta Korbonits ${ }^{7}$ and Pinaki Dutta ${ }^{1}$ \\ 'Department of Endocrinology, Postgraduate Institute of Medical Education and Research (PGIMER), Chandigarh, India \\ 2Department of Histopathology, PGIMER, Chandigarh, India \\ ${ }^{3}$ Department of Translational and Regenerative Medicine, PGIMER, Chandigarh, India \\ ${ }^{4}$ Department of Radiology, PGIMER, Chandigarh, India \\ ${ }^{5}$ Department of Pathology and Laboratory Medicine, Medanta, The Medicity, Gurgaon, India \\ ${ }^{6}$ Department of Neurosurgery, PGIMER, Chandigarh, India \\ ${ }^{7}$ Centre for Endocrinology, William Harvey Research Institute, Barts and The London School of Medicine and Dentistry, Queen Mary University of London, \\ London, UK \\ ${ }^{8}$ Green Templeton College, University of Oxford, Oxford, UK
}

Correspondence should be addressed to P Dutta: drpinakidutta12@gmail.com

\begin{abstract}
Objective: Posterior pituitary tumours (PPTs) are rare neoplasms with the four recognised subtypes unified by thyroid transcription factor -1 (TTF-1) expression, according to the 2017 WHO classification. Though traditionally defined as low-grade neoplasms, a substantial proportion of them show recurrence/persistence following surgery. Methods: We selected patients with PPTs in our cohort of 1760 patients operated for pituitary tumours over the past 10 years (2010-2019). The clinical, radiological, hormonal, histopathological profiles and long-term outcomes of the three cases identified (two pituicytomas and one spindle cell oncocytoma, SCO) were analysed. Following a literature review, data of all published cases with documented TTF-1 positive pituicytomas and SCOs were analysed to determine the predictors of recurrence/ persistence in these tumours.

Results: Patients presented with compressive features or hypogonadism. Two had sellarsuprasellar masses. One had a purely suprasellar mass with a pre-operative radiological suspicion of pituicytoma. Two were operated by transsphenoidal surgery and one transcranially guided by neuronavigation. Histopathology confirmed spindle cells in a storiform arrangement and low Ki67 index. Immunohistochemistry showed positive TTF-1, S-100 expression and variable positivity for EMA, vimentin and GFAP. Re-evaluation showed recurrence/persistence in two patients. A literature review of recurrent/persistent pituicytoma $(n=17)$ and SCO $(n=9)$ cases revealed clinical clues (headache for pituicytomas, male gender for SCO), baseline tumour size ( $\geq 20.5 \mathrm{~mm}$ with sensitivity exceeding $80 \%$ ) and longer follow-up duration as determinants of recurrence/persistence.

Conclusion: PPTs are rare sellar masses with quintessential TTF-1 positivity. Recurrent/ persistent disease following surgery is determined by greater tumour size at baseline and duration of follow-up. This warrants intensive and long-term surveillance in these patients.
\end{abstract}

\section{Key Words}

- pituicytomas

- posterior pituitary tumours

- spindle cell oncocytomas

- TTF-1 


\section{Introduction}

Posterior pituitary tumours (PPTs) are rare and comprise less than $0.5 \%$ of all sellar masses $(1,2)$. They represent a spectrum of a unique nosological entity characterised by the expression of the homeobox transcription factor TTF-1, a histological marker of normal pituicytes (3). Their most common mode of presentation is with mass effects and/or deficiency of anterior pituitary hormones (4). Rarely, they can be associated with anterior pituitary hyperfunction (acromegaly or Cushing's syndrome) $(5,6,7)$; however, posterior pituitary dysfunction (diabetes insipidus (DI)) is virtually never seen prior to surgery (4). PPTs are usually seen as suprasellar or sellar-suprasellar masses with no pathognomonic radiologic features $(4,8)$ except the rarely reported early intense contrast enhancement ('Hasiloglu's sign') or the presence of proteinaceous material appearing as a T1-hypointensity on MRI ('star crack sign') (9, 10). These tumours are in fact, more often than not, a histological surprise. Regardless, diffuse nuclear positivity for TTF-1 is the sine qua non of these tumours, as delineated in the latest WHO classification in 2017. Since the classification of anterior pituitary tumours has moved to a transcription-factor based classification, a similar move could be envisaged using positive immunostaining for the TTF- 1 transcription factor as a key characteristic of all PPTs.

Pituicytomas and the related sellar ependymomas, spindle cell oncocytomas (SCO) and granular cell tumours (GCT) are the different subtypes of PPTs (3) showing close clustering in methylation-based classification studies, suggesting they may have shared histogenesis, yet distinctive morphology $(11,12,13,14)$. Recently, a new subtype, namely primary papillary epithelial tumour of the sella (PPETS), has been identified as a distinct entity expressing TTF-1 (15). Rarely, mixed histopathological characteristics have also been described. Surgery is the treatment of choice for symptomatic PPT usually by the transsphenoidal route (TSS). However, PPTs, including both pituicytomas and SCOs, often show recurrence/ persistence following surgery $(16,17,18,19,20,21,22$, $23,24,25,26,27,28,29,30,31,32,33,34,35,36,37,38$, $39,40,41,42,43,44,45,46,47,48,49,50,51,52,53,54$, $55,56,57,58,59,60,61,62,63,64,65,66,67$ ).

The rates of recurrent/persistent disease vary between various tumour types, occurring in up to two-thirds of all cases, and higher with SCOs (66\%) than with pituicytomas (44\%) (4).

PPTs, which are close clinical and radiologic mimics of non-functioning pituitary adenomas (NFPAs), show rates of disease recurrence/persistence similar to NFPAs $(68,69)$, but over a much shorter duration of follow-up. While the determinants of recurrent/persistent disease in NFPAs include tumour size, the extent of resection and cavernous sinus invasion $(69,70)$, data on the prevalence and predictors of recurrence/persistence of PPTs are scarce. Invasiveness, high vascularity and consequent subtotal excision, and high proliferation indices, may all be plausible reasons for disease recurrence/ persistence but have sparingly been investigated in the context of PPTs. Cavernous sinus invasion in pituicytomas is rare (3\%) (26), thereby suggesting other factors that could be playing a major role in determining disease recurrence/persistence. It is crucial to identify the determinants of recurrence/persistence so as to not only prognosticate and identify at-risk individuals, but also ensure timely follow-up and management.

In this study, we describe a cohort of PPTs including two pituicytomas and one SCO identified in over 1760 cases of sellar-suprasellar masses operated at our institute over the past 10 years. The current study also aimed to identify the prevalence and determinants of recurrent/ persistent pituicytomas and SCOs by performing a literature review of all such TTF-1 positive cases with recurrent/persistent disease, and comparing them with those who had disease remission following surgery.

\section{Materials and methods}

\section{Cases from our centre}

Between January 2010 and December 2019, there were two cases of histopathologically proven pituicytoma and one case of SCO at our institute. Their clinical, radiologic and hormonal profiles were analysed. Histopathological analysis followed by immunohistochemistry (IHC) was performed on paraffin-embedded tissue sections. Antigen retrieval was performed after deparaffinisation of tissue sections and sections were stained for the following antibodies: TTF-1, vimentin, EMA, S-100, GFAP, chromogranin A, Ki67, GH, PRL, TSH, LH, FSH, and FSH- $\alpha$ (Bio-Rad \#0100-0662, 1:300) primary antibodies (Supplementary Table 1, see section on supplementary materials given at the end of this article). Slides were incubated with UltraVision ONE HRP Polymer and incubated for $30 \mathrm{~min}$ at room temperature (TL-015-HDJ, Thermo Scientific $\left.{ }^{\mathrm{TM}}\right)$. The signal was developed using DAB (TL-015-HDJ, Thermo Scientific ${ }^{\mathrm{TM}}$ ). Distribution of staining was scored by the pathologist as $0-3$. 
Institutional Ethics Committee clearance (IEC/6185/ Study/127) and written informed consent was obtained from all patients or next of kin, as appropriate.

\section{Literature search}

The literature was retrieved over the past three decades using Pubmed, Medline and Google scholar databases. Keywords searched alone or in combination included 'pituicytoma', 'spindle cell oncocytoma', 'recurrent', 'persistent', 'posterior', 'pituitary' and 'tumour'. Potential studies were also searched by assessing the citations in published studies and reviews. The following inclusion criteria were used in the search strategy: (1) patients with pituicytoma or SCO confirmed by histopathology and expressing TTF-1; (2) patients with recurrence or persistence following surgery; (3) studies reported in English literature. The following exclusion criteria were used: (1) studies reporting pituicytoma or SCO not managed by surgery or not documented to have recurrence or persistence; (2) studies making no mention of or negative TTF-1. We used a worksheet to compile information including clinical parameters (age, gender, presenting features, hypopituitarism), radiologic features (location, dimensions, contrast enhancement), surgical complications (blood loss), histopathological examination (including IHC) and outcomes (adjunctive therapy, follow-up duration). Studies were included based on their available histopathology and IHC reports. Published images were not reviewed by our histopathologist.

\section{Statistical analysis}

Statistical analysis was performed using the Statistical Package for Social Sciences (SPSS) 22.0 software programme (IBM Statistics 22.0). Pearson's chi-square and Fisher's exact test were used for categorical variables, while the t-test or Mann-Whitney tests were applied for continuous variables, as applicable. Derived receiver-operating curves (ROC) were used to determine tumour size with maximum sensitivity and specificity for the prediction of recurrence/ persistence.

\section{Results}

\section{Patient 1}

A 32-year-old female presented with intermittent headache and giddiness for 7 years (Table 1).
She had borne three children, the youngest one 8 years previously. On examination, she had coarse facies but there was no acral enlargement, sweating, or seborrhoea, thyrotoxicosis or stigmata of Cushing's syndrome. She had normal periods. Visual acuity, visual fields and fundal examination were normal. Investigations revealed hyperprolactinaemia $(90 \mathrm{ng} / \mathrm{mL}$; normal range (N) 5-25 ng/mL) and secondary hypocortisolism (08:00 h cortisol $163 \mathrm{nmol} / \mathrm{L}$; N 171-536 nmol/L, ACTH $6.4 \mathrm{pg} / \mathrm{mL}$ ). Her gonadotrophins were normal (LH $4.5 \mathrm{mIU} / \mathrm{mL}$; N 2-12.6 mIU/mL, FSH $7.5 \mathrm{mIU} / \mathrm{mL}$; N $1.8-12.8 \mathrm{mIU} / \mathrm{mL}$ ) with a plasma oestradiol of $41 \mathrm{pg} / \mathrm{mL}$ (N 12.5-166 pg/mL). Serum IGF-I (220 ng/mL; N 115-307 ng/mL) and T4 $(7.80 \mu \mathrm{g} / \mathrm{dL} ; \mathrm{N} 4.8-12 \mu \mathrm{g} / \mathrm{dL})$ were also within normal limits. MRI showed a sellar-suprasellar mass (Fig. 1A, B, $\mathrm{C}$ and D). She underwent microscopic endonasal TSS. Intra-operative findings showed a firm and vascular tumour, which was subject to gross total excision. The post-operative period was uneventful. Histopathology revealed a SCO with ultrastructure showing abundant mitochondria (Supplementary Fig. 1). Following surgery, she developed secondary hypothyroidism and was initiated on L-thyroxine. An ACTH stimulation test, performed 6 weeks following surgery after withholding hydrocortisone for $24 \mathrm{~h}$, showed a peak $30 \mathrm{~min}$ serum cortisol of $786 \mathrm{nmol} / \mathrm{L}$, hence hydrocortisone was discontinued. Post-operatively, prolactin normalised (18 ng/mL), suggesting that the hyperprolactinaemia was most likely due to stalk compression, and her menstrual cycles continued normally. Recurrence was observed 3 years later which remained static over the next 2 years (Fig. 1E, F, G and H). She is now under surveillance in view of the lack of significant change in size, and no new hormonal deficit.

\section{Patient 2}

A 53-year-old male presented with headache, pressure symptoms and diminished vision in his left eye followed by his right eye 6 months later (Table 1). He underwent TSS in 2010 at an outside hospital. There was an improvement in his vision, only to deteriorate a year later. Re-evaluation showed regrowth of residual disease $(3.2 \times 3 \times 2.9 \mathrm{~cm}$ sellar mass), necessitating a repeat TSS performed at the same hospital in 2012. Following the second surgery, the patient noted transient improvement in vision but complained of lethargy and low mood. On subsequent evaluation in 2014 at our hospital, he had bitemporal hemianopia, secondary hypocortisolism (serum cortisol $93 \mathrm{nmol} / \mathrm{L} ; \mathrm{N}$ $171-536 \mathrm{nmol} / \mathrm{L}$ ) and hypogonadism (serum testosterone

This work is licensed under a Creative Commons Attribution-NonCommercial-NoDerivatives 4.0 International License ifica com at $04 / 26 / 2023$ 08:10:35AM 
Table 1 Clinical, radiologic, hormonal and histopathological details of our three patients with posterior pituitary tumours.

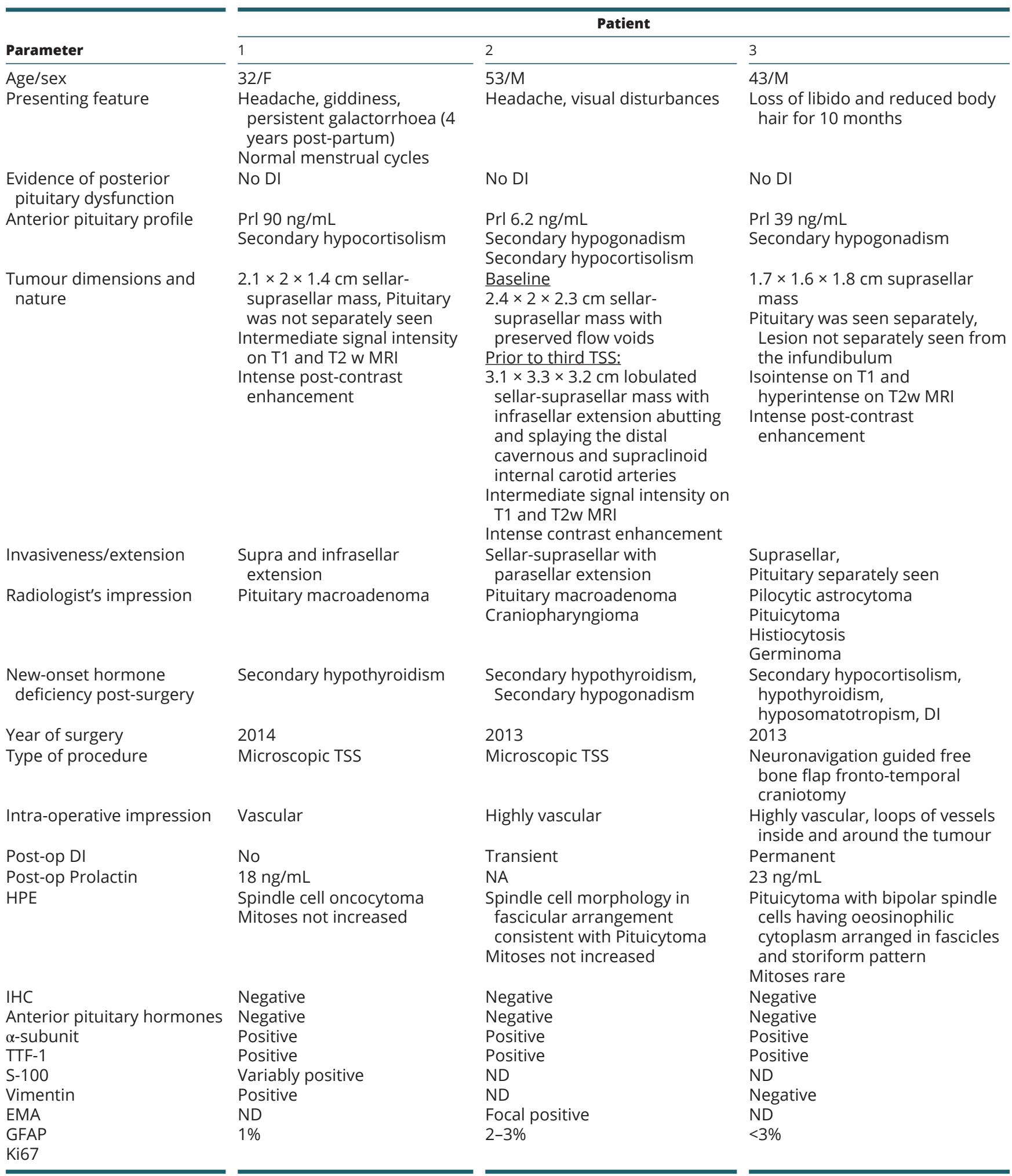

https://ec.bioscientifica.com https://doi.org/10.1530/EC-20-0621 (c) 2021 The authors Published by Bioscientifica Ltd
This work is licensed under a Creative Commons Attribution-NonCommercial-NoDerivatives 4.0 elnternationad dicense ifica. com at 04/26/2023 08:10:35AM 
Table 1 Continued

\begin{tabular}{|c|c|c|c|}
\hline \multirow[b]{2}{*}{ Parameter } & \multicolumn{3}{|c|}{ Patient } \\
\hline & 1 & 2 & 3 \\
\hline Post-op MRI residue & $\begin{array}{l}\text { Post-operative changes ( } 3 \\
\text { months post-operative) } \\
\text { No residue (First to third } \\
\text { post-operative years) } \\
0.9 \times 0.8 \times 1 \mathrm{~cm} \text { recurrence } \\
\text { abutting cavernous sinus } \\
\text { (Fourth post-operative year) } \\
0.8 \times 0.7 \times 1.1 \mathrm{~cm} \text { recurrence } \\
\text { (Fifth post-operative year) } \\
0.8 \times 0.8 \times 1.0 \mathrm{~cm} \text { recurrence } \\
\text { (Sixth post-operative year) }\end{array}$ & $\begin{array}{l}\text { Residue }(2.4 \times 2 \times 2.3 \mathrm{~cm}) \text { after } \\
\text { two previous TSS, for which he } \\
\text { was subjected to repeat TSS }\end{array}$ & $\begin{array}{l}\text { Post-operative changes seen } \\
\text { No significant residue ( } 3 \text { months } \\
\text { post-operative and in } \\
\text { subsequent MRIs, last done } 7 \\
\text { years post-operatively) }\end{array}$ \\
\hline Adjunctive therapy & None & None & None \\
\hline Outcome & Alive & Dead & Alive \\
\hline Cause of death & NA & $\begin{array}{l}\text { Hospitalised for pneumonia } \\
\text { Accelerated hypertension } \\
\text { causing intracerebral bleed }\end{array}$ & NA \\
\hline Duration of follow-up & 6 years & 5 years & 7 years \\
\hline
\end{tabular}

DI, diabetes insipidus; EMA, epithelial membrane antigen; GFAP, glial fibrillary acid protein; HPE, histopathology; IHC, immunohistochemistry; NA, not available; Prl, prolactin; TSS, transsphenoidal surgery.

$0.3 \mathrm{nmol} / \mathrm{L} ; \quad \mathrm{N} \quad 9-27 \mathrm{nmol} / \mathrm{L}, \quad \mathrm{LH} \quad 0.5 \mathrm{mIU} / \mathrm{mL} ; \quad \mathrm{N}$ 2-12.6 mIU/mL, FSH 0.23 mIU/mL; N 1.8-12.8 mIU/mL). Serum ACTH was not available, but was assumed to be due to secondary adrenal insufficiency in view of a large sellar mass and no features of primary insufficiency like hyperpigmentation or any obvious cause for the same. His serum prolactin $(6.2 \mathrm{ng} / \mathrm{mL}, \mathrm{N} \mathrm{5-20} \mathrm{ng/mL)} \mathrm{and} \mathrm{T4}$ (6.5 $\mu \mathrm{g} / \mathrm{dL} ; \mathrm{N} 4.8-12 \mu \mathrm{g} / \mathrm{dL}$ ) were normal. Prior histopathology was reported as NFPA elsewhere but was confirmed as a case of pituicytoma on review of the
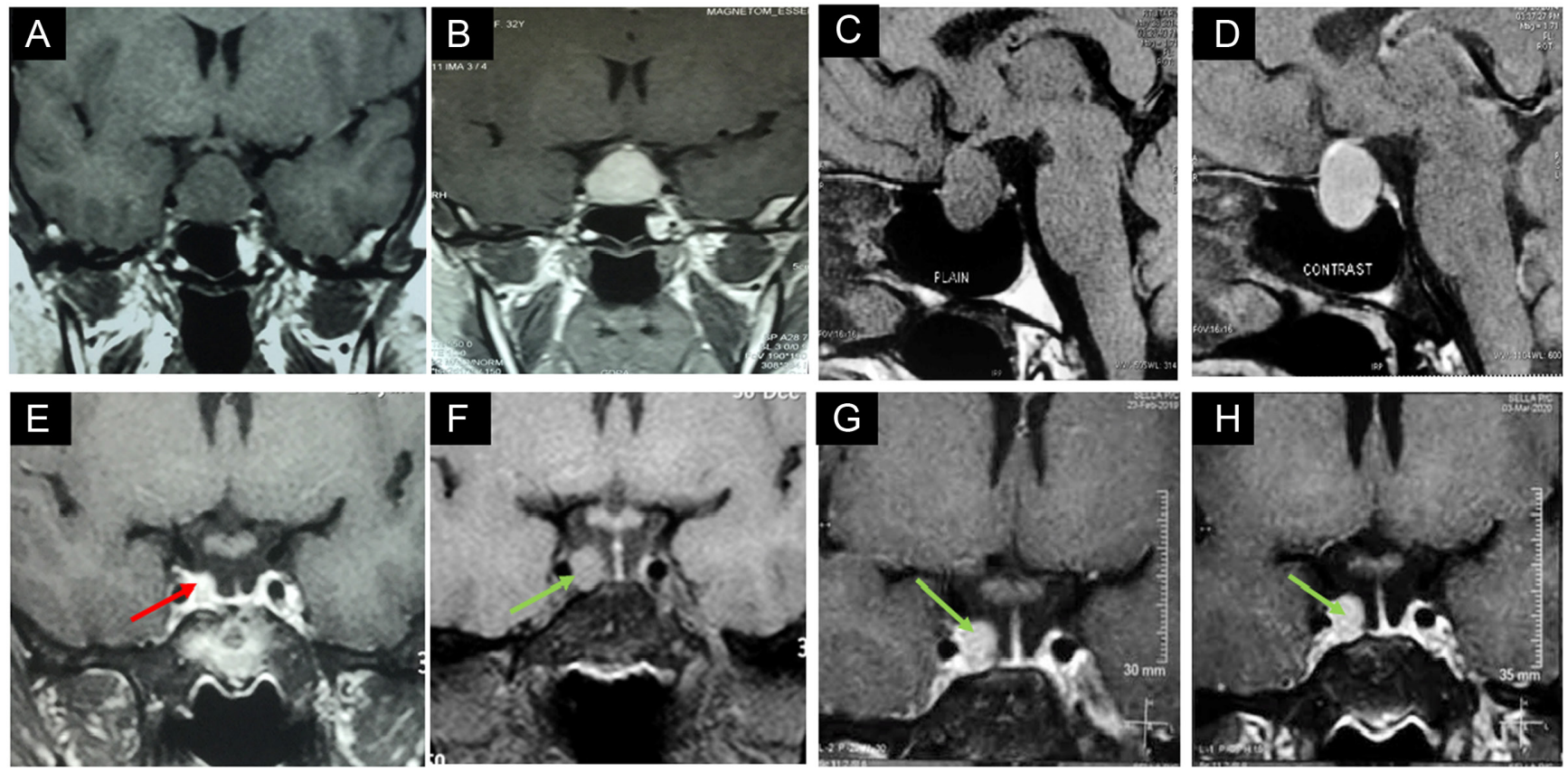

\section{Figure 1}

Panel of MRI images of Patient 1 (spindle cell oncocytoma). (A) showing a sellar-suprasellar mass $(2.1 \times 2 \times 1.4 \mathrm{~cm})$ abutting the optic chiasm and partially encasing both cavernous sinuses with preserved flow voids showing uniform enhancement on contrast administration (B). Sagittal MRI images without (C) and with (D) contrast show the sellar mass with a suprasellar extension. The pituitary and stalk are not separately visible. Bottom panel (E, F, G and H) shows post-operative MRI images of patient 1 with $(E)$ showing post-operative changes (red arrow) and subsequent yearly images $(F, G$ and $H)$ showing a right-sided intrasellar recurrence $(0.8 \times 0.7 \times 1.0 \mathrm{~cm})$ which has remained stable over the past 3 years (green arrows).

https://ec.bioscientifica.com https://doi.org/10.1530/EC-20-0621 (c) 2021 The authors Published by Bioscientifica Ltd

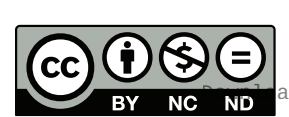

This work is licensed under a Creative Commons Attribution-NonCommercial-NoDerivatives 4.0 elnternationab ficense.ifica.com at 04/26/2023 08:10:35AM 
histopathological preparations at our institute. MRI at our institute showed a $3.1 \times 3.3 \times 3.2 \mathrm{~cm}$ sellar-suprasellar lesion. The patient underwent repeat microscopic TSS in 2014, via the left endonasal approach. Intra-operatively, the neurosurgeon found a firm, moderately vascular, greyish-white tumour. He performed subtotal excision (about $40 \%$ of the mass) but the procedure had to be truncated due to torrential bleeding. Histopathology showed a pituicytoma. The patient had transient DI requiring short-term vasopressin injections and was discharged on hydrocortisone, thyroxine and testosterone replacement. The visual acuity pre-TSS (third time) was $6 / 18$ in his right eye and 6/60 in the left eye. Post TSS, it did not improve and remained the same (6/18 in right eye and 6/60 in left eye). He was lost to follow-up, but 5 years after the last surgery he developed accelerated hypertension leading to an intracerebral bleed and died of pneumonia.

\section{Patient 3}

A 42-year-old male presented with loss of libido and reduced body hair in androgen-dependent areas (Table 1).

MRI revealed a suprasellar mass, with the infundibulum not seen separately (Fig. 2A, B, C and D).
He underwent transcranial surgery aiming for gross total resection in view of the pure suprasellar location of the mass. A highly 'fleshy' and vascular tumour was found intra-operatively, with multiple feeding vessels extending to the optic chiasma. Histopathology showed a pituicytoma (Fig. 3A, B, C and D). The patient developed permanent DI which was managed with intranasal desmopressin. Post-operative MRI did not show any residual tumour. He is doing well without any residual disease documented on repeat MRI after 84 months of follow-up.

\section{Analysis of published data on TTF-1 positive pituicytomas and SCOs}

A literature review was performed to identify those with recurrent/persistent pituicytoma or SCO and compared them with those having remission of disease in the past three decades. Only those tumours with documented TTF-1 positivity were included for the analysis. Of the 66 cases identified in the literature, 30 were pituicytomas with no disease recurrence/persistence while 17 pituicytomas had recurrence/persistence including one each from our series in both subgroups. Furthermore, there were 10 SCOs with no disease recurrence/persistence and 9 SCOs with disease recurrence/persistence including one patient
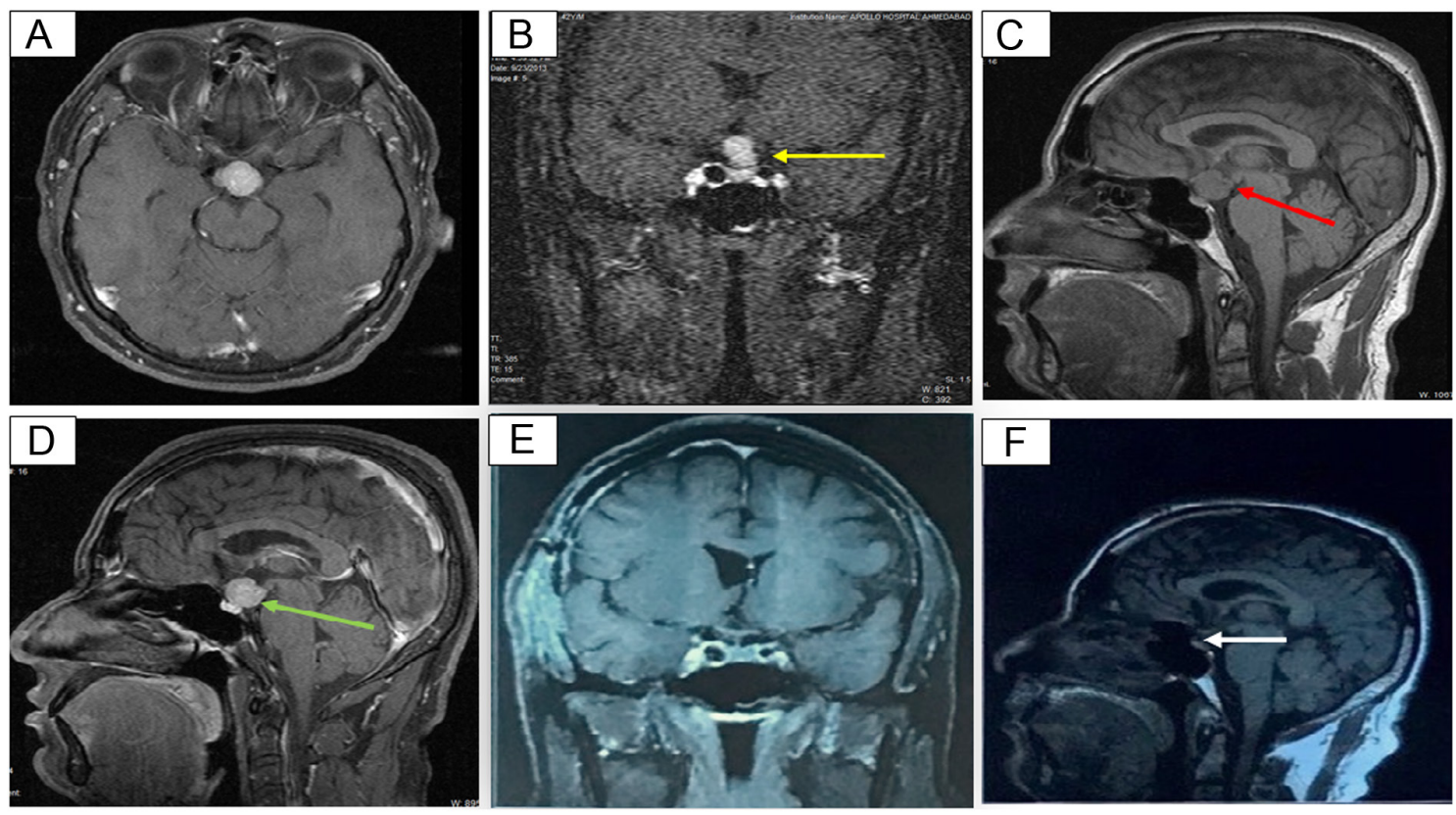

\section{Figure 2}

MRI of Patient 3 (pituicytoma) with the top panel showing a homogeneously enhancing well-defined mass $(1.7 \times 1.6 \times 1.8 \mathrm{~cm})$ on axial sections $(A)$ in the sellar region and (B) showing a pure suprasellar mass (yellow arrow) with the pituitary seen separately from the lesion. The mass reaches the floor of the third ventricle and bilateral cavernous flow voids are maintained. Bottom panel ((C) without contrast and (D) with contrast, red and green arrows) showing sagittal sections of the same suprasellar mass in which the mass seems to be abutting/arising from the stalk while the pituitary is clearly separate from the lesion. ( $E$ and F) show the post-operative MRI of the patient with no tumour residue (white arrow).

https://ec.bioscientifica.com https://doi.org/10.1530/EC-20-0621 (c) 2021 The authors Published by Bioscientifica Ltd

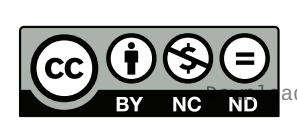

This work is licensed under a Creative Commons Attribution-NonCommercial-NoDerivatives 4.0 enternationab dficense.ifica.com at 04/26/2023 08:10:35AM 

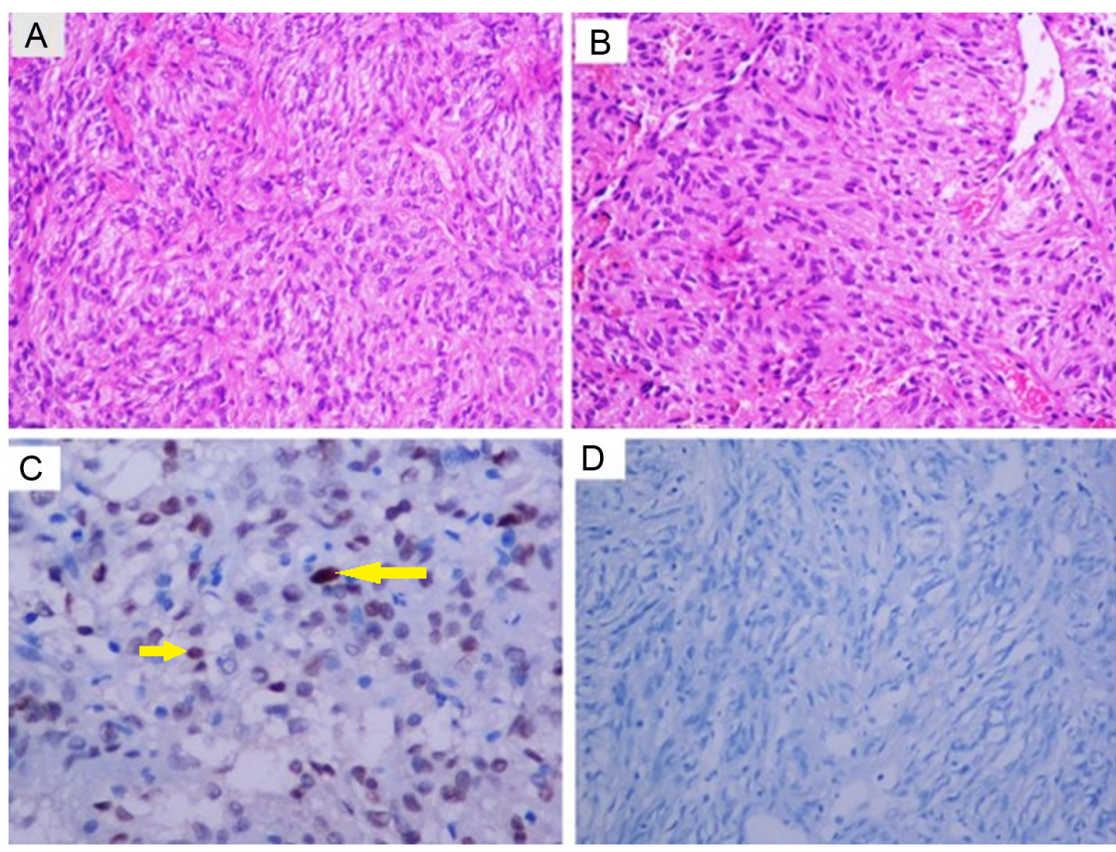

\section{Figure 3}

Photomicrographs (A and B) show tumour cells arranged in organoid pattern and small groups separated by fine fibrovascular septae. Individual tumour cells are oval to spindle-shaped with pale oeosinophilic moderate-to-abundant fibrillary cytoplasm (H\&E staining, $\times 400$ ). (C) shows nuclear positivity staining (marked by arrows) for immunohistochemistry for thyroid transcription factor 1 (TTF-1) (peroxidase anti-peroxidase, $\times 500$, yellow arrows). (D) shows negative immunohistochemistry staining for epithelial membrane antigen.

from the current series. Pooled analysis of patient data pertaining to clinical, radiological, histopathological and immunohistochemical characteristics and duration of follow-up are summarised in Tables 2, 3 and Supplementary Table 2.

There was no significant difference in age or gender predilection in case of pituicytomas having recurrent/persistent disease as compared to those who went into remission. However, recurrent/persistent tumours were more likely to have headache ( $47 \%$ vs $17 \%$, $P=0.04)$ and visual disturbances at baseline (71\% vs $47 \%$, $P=0.11)$. In line with these findings, baseline tumour dimensions were also significantly greater in those who had recurrence/persistence of disease following surgery

Table 2 Comparative analysis of TTF-1 positive pituicytomas in the literature with disease recurrence/persistence vs those with disease remission.

\begin{tabular}{|c|c|c|c|c|}
\hline Category & Parameter & $\begin{array}{l}\text { Pituicytomas with no } \\
\text { recurrence/persistence }(n=29+1)\end{array}$ & $\begin{array}{c}\text { Pituicytomas with } \\
\text { recurrence/persistence }(n=16+1)\end{array}$ & $P$ value \\
\hline \multirow{4}{*}{$\begin{array}{l}\text { Demographic and } \\
\text { clinical parameters }\end{array}$} & Male (\%) & 50 & 41 & 0.76 \\
\hline & Age (years) & $48.4 \pm 14.7$ & $53.7 \pm 14.4$ & 0.23 \\
\hline & Visual defects (\%) & 47 & 71 & 0.11 \\
\hline & Headache $(\%)$ & 17 & 47 & 0.04 \\
\hline \multirow{4}{*}{$\begin{array}{l}\text { Radiological } \\
\text { characteristics }\end{array}$} & Sellar & 36 & 29 & 0.09 \\
\hline & Suprasellar & 28 & 6 & \\
\hline & Sellar-Suprasellar & 36 & 65 & \\
\hline & Maximum diameter $(\mathrm{mm})$ & $16.6 \pm 6.8 \mathrm{~mm}$ & $29.7 \pm 13.6 \mathrm{~mm}$ & 0.001 \\
\hline \multirow[t]{2}{*}{ Surgical details } & Initial choice of surgery TSS & 80 & 80 & 1.00 \\
\hline & Bleeding (\%) & 36 & 41 & 0.75 \\
\hline \multirow{7}{*}{$\begin{array}{l}\text { Histopathological } \\
\text { evaluation }\end{array}$} & $\mathrm{IHC}$ & & & \\
\hline & S-100 (\%) & 100 & 100 & - \\
\hline & TTF-1 (\%) & 100 & 100 & - \\
\hline & Vimentin (\%) & 100 & 100 & - \\
\hline & EMA (\%) & 29 & 50 & 0.57 \\
\hline & GFAP $(\%)$ & 43 & 41 & 0.88 \\
\hline & $\mathrm{Ki} 67 \%$ & $2.97 \pm 1.62$ & $3.82 \pm 3.39$ & 0.84 \\
\hline \multirow{2}{*}{$\begin{array}{l}\text { Post-operative } \\
\text { course }\end{array}$} & Multiple surgeries (2 or more) (\%) & - & 6 & \\
\hline & Adjunctive RT (\%) & - & 18 & \\
\hline Follow-up & Follow up duration (months) & $17(9-54)$ & $60(25-84)$ & 0.05 \\
\hline
\end{tabular}

EMA, epithelial membrane antigen; GFAP, glial fibrillary acid protein; IHC, immunohistochemistry; RT, radiotherapy; TSS, transsphenoidal surgery; TTF-1, thyroid transcription factor-1.

https://ec.bioscientifica.com https://doi.org/10.1530/EC-20-0621 (c) 2021 The authors Published by Bioscientifica Ltd

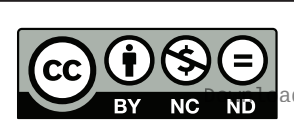

This work is licensed under a Creative Commons Attribution-NonCommercial-NoDerivatives 4.0 internationad bicense ifica . com at $04 / 26 / 2023 \quad 08: 10: 35 \mathrm{AM}$ 
Table 3 Comparative analysis of TTF-1 positive spindle cell oncocytomas (SCO) in the literature with disease recurrence/ persistence vs those with disease remission.

\begin{tabular}{|c|c|c|c|c|}
\hline Category & Parameter & $\begin{array}{l}\text { Spindle cell oncocytomas with no } \\
\text { recurrence/persistence }(n=10)\end{array}$ & $\begin{array}{l}\text { Spindle cell oncocytomas with } \\
\text { recurrence/persistence }(n=8+1)\end{array}$ & $P$ value \\
\hline Demographic and & Male (\%) & 10 & 56 & 0.05 \\
\hline \multirow[t]{3}{*}{ Clinical parameters } & Age (years) & $49.5 \pm 18.0$ & $54.5 \pm 12.6$ & 0.48 \\
\hline & Visual defects (\%) & 60 & 78 & 0.62 \\
\hline & Headache (\%) & 30 & 44 & 0.65 \\
\hline \multirow{4}{*}{$\begin{array}{l}\text { Radiological } \\
\text { characteristics }\end{array}$} & Sellar & 20 & 14 & 0.43 \\
\hline & Suprasellar & 20 & 14 & \\
\hline & Sellar-Suprasellar & 60 & 72 & \\
\hline & Maximum diameter $(\mathrm{mm})$ & $20.7 \pm 6.7 \mathrm{~mm}$ & $27.5 \pm 8.0 \mathrm{~mm}$ & 0.07 \\
\hline \multirow[t]{2}{*}{ Surgical details } & Initial choice of surgery TSS & 80 & 89 & 0.59 \\
\hline & Bleeding (\%) & 14 & 33 & 0.58 \\
\hline \multirow{7}{*}{$\begin{array}{l}\text { Histopathological } \\
\text { evaluation }\end{array}$} & $\mathrm{IHC}$ & & & \\
\hline & S-100 (\%) & 89 & 78 & 0.52 \\
\hline & TTF-1 (\%) & 100 & 100 & - \\
\hline & Vimentin (\%) & 100 & 100 & - \\
\hline & EMA (\%) & 100 & 85 & 0.29 \\
\hline & GFAP $(\%)$ & 20 & 11 & 0.59 \\
\hline & Ki67 \% & $4.83 \pm 3.61$ & $7.61 \pm 5.21$ & 0.25 \\
\hline \multirow[t]{2}{*}{ Post-operative course } & $\begin{array}{l}\text { Multiple surgeries } \\
\text { (2 or more) (\%) }\end{array}$ & - & 89 & \\
\hline & Adjunctive RT (\%) & - & 56 & \\
\hline Follow-up & $\begin{array}{l}\text { Follow up duration } \\
\text { (months) }\end{array}$ & $10.2(1.8-24.7)$ & $48(16.8-108)$ & 0.01 \\
\hline
\end{tabular}

EMA, epithelial membrane antigen; GFAP, glial fibrillary acid protein; IHC, immunohistochemistry; RT, radiotherapy; TSS, transsphenoidal surgery; TTF-1, thyroid transcription factor-1.

(29.7 $\pm 13.6 \mathrm{~mm}$ vs $16.6 \pm 6.8 \mathrm{~mm}, P=0.001)$. Rates of intra-operative bleeding and the proliferative index Ki-67 were not significantly different between both subgroups. The median follow-up duration was higher in those with disease recurrence/persistence (60 months vs 17 months, $P=0.05$ ).

In SCOs, there were more males with recurrent/ persistent disease $(56 \%$ vs $10 \%, P=0.05)$. Compressive features (headache, visual disturbances) were higher in those with disease recurrence/persistence, but it was not significant. Tumour dimensions were again higher in those with disease recurrence/persistence $(27.5 \pm 8 \mathrm{~mm}$ vs $20.7 \pm 6.7 \mathrm{~mm}$ ) with a trend towards significance $(P=0.07)$. Ki-67 and rates of intra-operative bleeding were similar in the two groups. Follow-up duration was greater in those who were documented to have recurrent/ persistent disease (48 months vs 10.2 months, $P=0.01$ ). ROC analysis revealed a maximum tumour dimension of $20.5 \mathrm{~mm}$ (AUC $0.855, P=0.001$ ) as having $82 \%$ sensitivity and $80 \%$ specificity for recurrence/persistence following surgery in the case of pituicytomas and $20.5 \mathrm{~mm}$ (AUC $0.781, P=0.081$ ) as having $83 \%$ sensitivity and $63 \%$ specificity in case of SCOs (Supplementary Figs 2 and 3).

Combined analysis of recurrent/persistent pituicytomas and SCOs mirrored similar findings of a higher prevalence of headache and larger tumour dimensions (Supplementary Table 2). Overall, in this cohort limited to TTF-1 positive pituicytomas and SCOs, there was a $39.3 \%$ prevalence of disease recurrence/ persistence. Duration of follow-up was also significantly higher in those with recurrent/persistent disease (54 months vs 15 months, $P=0.006$ ). Clinical and radiological profiles of patients with recurrent/persistent pituicytomas and SCOs were similar between both groups, except for the proliferation index and use of adjuvant therapy, which were higher in SCOs. Among IHC markers, vimentin emerged as a constant marker of pituicytomas and SCOs, irrespective of disease status following surgery. S-100 was more frequently positive in pituicytomas whereas EMA was more commonly positive in SCOs. One death was reported in each of the subtypes due to unrelated causes at 1 month post-operatively (an SCO case) and 14 months post-operatively (pituicytoma).

\section{Discussion}

The current study bears testimony to the extreme rarity of posterior pituitary tumours in our tertiary referral centre for sellar-suprasellar masses. There were two cases 
of pituicytomas, one of whom had multiple recurrences and multiple operations, but he ultimately succumbed due to an unrelated cause, while another had a complete cure following a transcranial approach and is still under follow-up. The third patient had an SCO and is under follow-up with a persistent, non-proliferative disease. The mean duration of follow-up was 72 months. A literature review of all cases of TTF-1 positive recurrent/persistent pituicytomas and SCOs as compared to those who had disease remission following surgery showed a higher prevalence of headache and larger tumours, albeit with a longer duration of follow-up. The current study provides evidence for maintaining long-term follow-up in patients with posterior pituitary tumours so as to identify disease recurrence/persistence, especially in those with larger tumours at baseline.

The posterior pituitary is composed of pituicytes and terminal axons from the magnocellular neurons originating in supra-optic and paraventricular nuclei of the hypothalamus. In the past, PPTs had a nomenclature varying from 'infundibuloma', and 'choristoma' to pilocytic astrocytoma (71). The first description of a pituicytoma was probably by Scothorne in 1955 (72). Oncocytomas, on the other hand, have a less clearcut background. They were originally reported as adenohypophyseal tumours originating from folliculostellate cells (non-endocrine cells in the anterior pituitary) by Roncaroli et al. in 2002 (73). However, later research by Mete and Lee confirmed the origin of SCOs from the posterior pituitary following the demonstration of TTF-1 positivity, the marker specific to the posterior pituitary $(13,74)$. The classification of pituicytes into different types, based on certain ultrastructural characteristics, has led to the recognition of different tumour subtypes: 'dark/ major' pituicytes forming pituicytomas with 'ependymal pituicytes' probably belonging to the same subgroup, 'oncocytic' pituicytes forming SCO and 'granular' pituicytes forming GCT $(11,12,13)$. Further studies are needed to decide if the recently described PPETS (15) may also belong to the PPT group. Electron microscopy findings, however, show spindle cell morphology in both pituicytomas and SCOs. Pituicytomas additionally have intermediate filaments and no secretory granules (34). SCOs are characterised by abundant mitochondria which may show lamellar cristae formation. Focal duplicated basal lamina, a variable number of mitochondria, lysosomes and desmosomes and tight intercellular junctions may be seen in both pituicytomas and SCOs.

TTF-1 (also known as Nkx-2.1) is a homeobox transcription factor well known for its involvement in thyroid and lung development. It is also expressed in the ventral forebrain and pituitary in rodents and in normal human pituicytes which originate from the ventral ectoderm (74). In a prior study, TTF-1 was found to be positively expressed in all subtypes of PPTs and was negative in normal or tumoral adenohypophyseal tissue (75). A recent study has reported a new entity PPETS, also expressing TTF-1 (15). Though certain anterior pituitary adenomas may sometimes show oncocytic changes (especially gonadotrophinomas, null cell adenomas and rarely silent corticotroph adenomas), they lack TTF-1 positivity, in contrast to true SCOs which arise from the posterior pituitary. It is clear that diffuse nuclear positivity for the transcription factor TTF- 1 is the identifying marker for PPTs, including pituicytomas and SCOs.

The current study included all cases of PPTs managed at our institute over the past 10 years. In over 1760 operated cases of sellar-suprasellar masses, we had three cases of PPTs. This is in accordance with the extreme rarity of these tumours as previously reported from large registries, accounting for under $0.5 \%$ of sellar masses $(1,2)$. Only three cases of PPT (all GCT) were diagnosed during an 18-year period at the neuropathology database at the Massachusetts General Hospital (76). A recent systematic review summarised all cases of PPTs, totalling over 260. Nevertheless, when taking into account the presence of TTF-1 positivity which is regarded as the diagnostic hallmark of PPTs, the number of reported cases is much lower.

Pre-operative diagnosis is further complicated by the non-specific clinical features of patients at baseline. Two of our patients presented with compressive features (headache, visual disturbances) and one with hypogonadism. This is in concordance with prior reports $(4,71)$. One of our patients (with SCO) presented with galactorrhoea associated with hyperprolactinaemia due to the stalk effect. This is a reported albeit uncommon presentation $(4,25)$ and it normalised following surgery. We did not observe features of anterior pituitary hyperfunction or posterior pituitary dysfunction at presentation. Rarely, patients with PPTs have been reported to present with acromegaly or Cushing's syndrome at baseline, attributed to co-existing anterior pituitary adenomas or release of putative stimulatory factors that could stimulate the anterior pituitary. Pre-operative DI is extremely rare $(<0.5 \%)$. This is probably due to the fact that the posterior pituitary reserve is normally much higher than normally required for water homeostasis (77).

Radiological clues to a pre-operative diagnosis are often extremely subtle, but some conclusions drawn from

This work is licensed under a Creative Commons Attribution-NonCommercial-NoDerivatives 4.0 elnternational License.ifica, com at $04 / 26 / 2023$ 08:10:35AM 
previous studies suggest that a purely sellar mass is most likely to be a pituicytoma, a purely suprasellar mass GCT and a mixed sellar-suprasellar mass an SCO (4). Others have suggested considering pituicytoma in suprasellar lesions (26) as was true in one of our patients (Patient $3)$. PPTs are hypervascular with an early intense contrast enhancement and vascular blush on angiography (22, 28). In line with this, there have been some reports of apoplexy $(40,54)$. The early enhancement is in contrast to a delayed and more gradual pattern seen with pituitary adenomas (78). PPTs, except when purely suprasellar and early intensely contrast enhancing, are difficult to distinguish radiologically from pituitary adenomas. However, a definitive pre-operative diagnosis is rarely possible, as reported in only one of our patients (Patient 3). This was useful as it led to an informed decision of a transcranial surgical approach which could have contributed to remission of disease in him.

Histopathology usually provides the final answer in the diagnosis of these tumours. The most common finding is the presence of spindle-shaped cells with a storiform or fascicular arrangement. IHC in reported cases has shown the variable and non-universal presence of TTF-1 despite it being regarded as the histological hallmark of these tumours. Among other IHC markers, S-100, vimentin, EMA, GFAP and galectin-3 have been reported in various series with GFAP positivity mostly in pituicytomas and EMA in SCO $(4,18)$. Furthermore, these tumours are negative for adenohypophyseal hormones and chromogranin A, indicating their histologically 'neuronal' rather than 'neuroendocrine' nature. We found TTF-1 and S-100 positivity in all of our patients. In one series of PPTs from Mexico $(n=16)$, TTF- 1 was positive in all and S-100 in $88 \%$ of patients (18), whereas in the series from the German Registry $(n=27)$, S-100 positivity was present in all but TTF-1 was positive in all 16 patients analysed (11). Although it was analysed in only these 16 samples, many earlier reports lacked analysis for TTF-1 since the identification of this marker as the defining feature of these tumours is fairly recent. Nevertheless, TTF- 1 being the defining feature of PPTs, we included only reports of pituicytomas and SCOs with documented TTF-1 positivity so as to maintain clarity and homogeneity.

One of our pituicytomas (Patient 2) showed multiple recurrences requiring many operations. The other one (Patient 3 ) was completely cured after the first surgery. The patient with SCO has been followed-up with an annual MRI evaluation, especially since she had post-operative changes, the nature of which could be confirmed only by prospective evaluation. The benign nature of PPTs was suggested by earlier reports, but a literature review in the current study points towards a more sinister course than might be expected from grade 1 neoplasms. Though they may clinically and radiologically mimic NFPAs, disease recurrence/persistence with PPTs is higher than with NFPAs. This is justified by a slightly higher prevalence of the non-remitting disease in case of PPTs, but with a much shorter mean duration of follow-up. While recent reviews have documented disease recurrence/persistence in nearly half of all NFPAs undergoing surgery over a mean duration of follow-up of nearly a decade, the recent systematic review on PPTs showed a non-remission rate varying from 50 to $60 \%$ over a much shorter follow-up duration $(4,78)$. Even in our pooled patient analysis of only TTF-1 positive neoplasms, there was a $39.3 \%$ prevalence of non-remitting disease. This tumour behaviour is seldom attributable to a high proliferation rate or invasiveness $(19,21,31$, $40,41,44,53,55)$. Interestingly, recurrence/persistence is also seen in tumours that are non-invasive and with a low proliferation rate $(\mathrm{Ki}-67<3 \%)(18,19,21,24,31,32)$. Other possible reasons for recurrent/persistent tumours include increased chances of intra-operative bleeding, suprasellar or cavernal sinus extension, and the adherent nature of these tumours which results in incomplete surgical excision $(16,19,24,26,29,51,54,62,63)$.

Our findings analysing a homogeneous cohort revealed headache and tumour size in TTF-1 positive pituicytomas and male gender and tumour size in TTF- 1 positive SCOs as important determinants of recurrence/persistence in these tumours. It is imperative and interesting to note that there was no greater risk of a higher proliferative index with recurrence/persistence, in consensus with prior reports. However, the fact that duration of follow-up is a direct determinant of disease recurrence/persistence in both subtypes, as identified by literature review in the current study, needs to be acknowledged and addressed in clinical settings. Though consensus on the optimal duration and frequency of surveillance is lacking primarily owing to lack of evidence (79), the current study provides a basis for future studies in this direction. A reasonable surveillance protocol would be to perform annual MRI examination for 5 years and biannually thereafter, especially in those with a cavernous sinus invasion or suprasellar extension of the residue, as has been suggested for NFPAs (80). This has important implications for clinical practice, including intensive follow-up for the early detection of recurrence or growth of tumour remnant. In a recent review of SCOs, the extent of resection (subtotal than gross total) 
was found to determine recurrence. However, that study analysed all SCOs, irrespective of TTF-1 positivity, which could account for the variance in findings (81).

Management of recurrent/persistent pituicytomas and SCOs involves the usage of adjuvant radiotherapy. Stereotactic radiosurgery has been successfully reported in achieving disease remission in clinically aggressive SCOs with recurrent/persistent disease following surgery (67). However, radiotherapy is probably under-utilised, as its use was noted in less than one-third patients in the pooled analysis. Medical management with the use of BRAF inhibitors, is anecdotal, having been reported in only two cases both of which were found to harbour V600E BRAF mutation $(66,82)$. VEGF and SSTR3,5 IHC have been documented positive in few cases, but have not found therapeutic application.

\section{Conclusions}

Posterior pituitary tumours are rare sellar tumours classified as TTF-1-positive grade 1 benign neoplasms. Determinants of recurrence/persistence include tumour size at baseline and duration of follow-up. Ascertainment of cases that are likely to recur using certain clinical (male gender for SCO, headache for pituicytoma) and radiological clues (maximum tumour dimension exceeding $20.5 \mathrm{~mm}$ ) can serve as useful pointers to identify those who require close, long-term follow-up by a dedicated multidisciplinary team.

\section{Supplementary materials}

This is linked to the online version of the paper at https://doi.org/10.1530/ EC-20-0621.

\section{Declaration of interest}

The authors declare that there is no conflict of interest that could be perceived as prejudicing the impartiality of the research reported.

\section{Funding}

This research did not receive any specific grant from any funding agency in the public, commercial or not-for-profit sector.

\section{Ethical approval}

Institutional Ethics Committee (IEC, PGIMER) ethical approval was obtained.

\section{Informed consent}

Written informed consent for publication was obtained from participants or their relatives as applicable.

\section{Author contribution statement}

All authors contributed equally to the study and in the writing of the manuscript.

\section{Acknowledgements}

The authors would like to acknowledge the neurosurgeon $\operatorname{Dr} \mathrm{A} N$ Jha (Medanta Hospital, Gurgaon, India) who operated Patient 3 and Prof Ashim Das (Department of Histopathology, PGIMER, India) who confirmed the histopathological diagnosis in Patient 1.

\section{References}

1 Famini P, Maya MM \& Melmed S. Pituitary magnetic resonance imaging for sellar and parasellar masses: ten-year experience in 2598 patients. Journal of Clinical Endocrinology and Metabolism 201196 1633-1641. (https://doi.org/10.1210/jc.2011-0168)

2 Saeger W, Lüdecke DK, Buchfelder M, Fahlbusch R, Quabbe HJ \& Petersenn S. Pathohistological classification of pituitary tumors: 10 years of experience with the German Pituitary Tumor Registry. European Journal of Endocrinology 2007156 203-216. (https://doi. org/10.1530/eje.1.02326)

3 Mete O \& Lopes MB. Overview of the 2017 WHO classification of pituitary tumors. Endocrine Pathology 201728 228-243. (https://doi. org/10.1007/s12022-017-9498-z)

4 Guerrero-Pérez F, Marengo AP, Vidal N, Iglesias P \& Villabona C. Primary tumors of the posterior pituitary: a systematic review. Reviews in Endocrine and Metabolic Disorders 201920 219-238. (https://doi.org/10.1007/s11154-019-09484-1)

5 Feng Z, Mao Z, Wang Z, Liao B, Zhu Y \& Wang H. Non-adenomatous pituitary tumours mimicking functioning pituitary adenomas. British Journal of Neurosurgery 201816 1-5.

6 Li X, Liu Y, Miao Y, Wang J, Wang L \& Wang EH. A rare case of pituicytoma presenting with severe Cushing disease: a case report and review of literature. Medicine 201998 e17772. (https://doi. org/10.1097/MD.0000000000017772)

7 Gezer E, Selek A, Cetinarslan B, Canturk Z, Tarkun I \& Ceylan S. The coexistence of infundibular pituicytoma and Cushing's disease due to pituitary adenoma: a case report. Endocrine Regulations 201953 263-267. (https://doi.org/10.2478/enr-2019-0026)

8 Cossu G, Brouland JP, La Rosa S, Camponovo C, Viaroli E, Daniel RT $\&$ Messerer M. Comprehensive evaluation of rare pituitary lesions: a Single Tertiary Care Pituitary Center Experience and Review of the Literature. Endocrine Pathology 201930 219-236. (https://doi. org/10.1007/s12022-019-09581-6)

9 Hasiloglu ZI, Ure E, Comunoglu N, Tanriover N, Oz B, Gazioglu N \& Mihmanli I. New radiological clues in the diagnosis of spindle cell oncocytoma of the adenohypophysis. Clinical Radiology 201671937. e5-937.e11. (https://doi.org/10.1016/j.crad.2016.04.022)

10 Han F, Gao L, Wang Y, Jin Y, Lv Y, Yao Z \& Zhang J. Clinical and imaging features of granular cell tumor of the neurohypophysis: a retrospective analysis. Medicine 201897 e9745. (https://doi. org/10.1097/MD.0000000000009745)

11 Hagel C, Buslei R, Buchfelder M, Fahlbusch R, Bergmann M, Giese A, Flitsch J, Lüdecke DK, Glatzel M \& Saeger W. Immunoprofiling of glial tumours of the neurohypophysis suggests a common pituicytic origin of neoplastic cells. Pituitary 201720 211-217. (https://doi. org/10.1007/s11102-016-0762-x)

12 Takei Y, Seyama S, Pearl GS \& Tindall GT. Ultrastructural study of the human neurohypophysis. II. Cellular elements of neural parenchyma, the pituicytes. Cell and Tissue Research 1980205 273-287. (https://doi.org/10.1007/BF00234685)

13 Mete O, Lopes MB \& Asa SL. Spindle cell oncocytomas and granular cell tumors of the pituitary are variants of pituicytoma. American

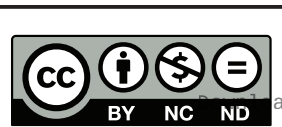

This work is licensed under a Creative Commons Attribution-NonCommercial-NoDerivatives 4.0 internationad bicense ifica com at 04/26/2023 08:10:35AM 
Journal of Surgical Pathology 201337 1694-1699. (https://doi. org/10.1097/PAS.0b013e31829723e7)

14 Capper D, Jones DTW, Sill M, Hovestadt V, Schrimpf D, Sturm D, Koelsche C, Sahm F, Chavez L, Reuss DE, et al. DNA methylationbased classification of central nervous system tumours. Nature 2018 555 469-474. (https://doi.org/10.1038/nature26000)

15 Roncaroli F, Chatterjee D, Giannini C, Pereira M, La Rosa S, Brouland JP, Gnanalingham K, Galli C, Fernandes B, Lania A, et al. Primary papillary epithelial tumour of the sella: expanding the spectrum of TTF-1-positive sellar lesions. Neuropathology and Applied Neurobiology 202046 493-505. (https://doi.org/10.1111/ nan.12622)

16 Lefevre E, Bouazza S, Bielle F \& Boch AL. Management of pituicytomas: a multicenter series of eight cases. Pituitary 201821 507-514. (https://doi.org/10.1007/s11102-018-0905-3)

17 Yoshida K, Toda M, Akiyama T, Takahashi S, Nishimoto M, Ozawa H, Ikari Y \& Yoshida K. Combined endoscopic endonasal and videomicroscopic transcranial approach with preoperative embolization for a posterior pituitary tumor. World Neurosurgery 2018119 201-208. (https://doi.org/10.1016/j.wneu.2018.07.245)

18 Guerrero-Pérez F, Vidal N, Marengo AP, Del Pozo CD, Blanco C, Rivero-Celada D, Díez JJ, Iglesias P, Picó A \& Villabona C. Posterior pituitary tumours: the spectrum of a unique entity. A clinical and histological study of a large case series. Endocrine 201963 36-43. (https://doi.org/10.1007/s12020-018-1774-2)

19 Vellutini EAS, Becker PHP, Godoy LF, Guerreiro NFC, Mattedi RL \& de Oliveira MF. Epithelioid pituicytoma: an unusual case report. Surgical Neurology International 20189 145. (https://doi.org/10.4103/sni. sni_319_17)

20 Chang TW, Lee CY, Jung SM, Lai HY, Chen CT, Yeap MC, Chuang CC, Hsu PW, Chang CN, Tu PH, et al. Correlations between clinical hormone change and pathological features of pituicytoma. British Journal of Neurosurgery 201832 501-508. (https://doi.org/10.1 080/02688697.2018.1472212)

21 Nagata Y, Inoshita N, Fukuhara N, Yamaguchi-Okada M, Nishioka H \& Yamada S. Low-grade glioma of the neurohypophysis: clinical characteristics and surgical outcomes. World Neurosurgery 2018114 e1225-e1231. (https://doi.org/10.1016/j.wneu.2018.03.180)

22 Shim HK, Cha SH, Cho WH \& Park SH. Pituicytoma with significant tumor vascularity mimicking pituitary macroadenoma. Brain Tumor Research and Treatment 20175 110-115. (https://doi.org/10.14791/ btrt.2017.5.2.110)

23 Wang J, Liu Z, Du J, Cui Y, Fang J, Xu L \& Li G. The clinicopathological features of pituicytoma and the differential diagnosis of sellar glioma. Neuropathology 201636 432-440. (https:// doi.org/10.1111/neup.12291)

24 Teti C, Castelletti L, Allegretti L, Talco M, Zona G, Minuto F, Boschetti M \& Ferone D. Pituitary image: pituicytoma. Pituitary 2015 18 592-597. (https://doi.org/10.1007/s11102-014-0612-7)

25 Zygourakis CC, Rolston JD, Lee HS, Partow C, Kunwar S \& Aghi MK. Pituicytomas and spindle cell oncocytomas: modern case series from the University of California, San Francisco. Pituitary 201518 150-158. (https://doi.org/10.1007/s11102-014-0568-7)

26 Feng M, Carmichael JD, Bonert V, Bannykh S \& Mamelak AN. Surgical management of pituicytomas: case series and comprehensive literature review. Pituitary 201417 399-413. (https://doi. org/10.1007/s11102-013-0515-z)

27 Tian Y, Yue S, Jia G \& Zhang Y. Childhood giant pituicytoma: a report and review of the literature. Clinical Neurology and Neurosurgery 2013 115 1943-1950. (https://doi.org/10.1016/j.clineuro.2013.07.032)

28 Ida CM, Yan X, Jentoft ME, Kip NS, Scheithauer BW, Morris JM, Dogan A, Parisi JE \& Kovacs K. Pituicytoma with gelsolin amyloid deposition. Endocrine Pathology 201324 149-155. (https://doi. org/10.1007/s12022-013-9254-y)

29 Huynh N, Stemmer-Rachamimov AO, Swearingen B \& Cestari DM. Decreased vision and junctional scotoma from pituicytoma.
Case Reports in Ophthalmology 20123 190-196. (https://doi. org/10.1159/000339242)

30 Secci F, Merciadri P, Rossi DC, D’Andrea A \& Zona G. Pituicytomas: radiological findings, clinical behavior and surgical management. Acta Neurochirurgica 2012154 649-657; discussion 657. (https://doi. org/10.1007/s00701-011-1235-7)

31 Islamian AP, Buslei R, Saeger W \& Fahlbusch R. Pituicytoma: overview of treatment strategies and outcome. Pituitary 201215 227-236. (https://doi.org/10.1007/s11102-011-0317-0)

32 Zunarelli E, Casaretta GL, Rusev B \& Lupi M. Pituicytoma with atypical histological features: are they predictive of unfavourable clinical course? Pathology 201143 389-394. (https://doi.org/10.1097/ PAT.0b013e32834687b3)

33 Brandão RA, Braga MH, de Souza AA, Reis BL \& de Lima FB. Pituicytoma. Surgical Neurology International 20101 79. (https://doi. org/10.4103/2152-7806.73802)

34 Phillips JJ, Misra A, Feuerstein BG, Kunwar S \& Tihan T. Pituicytoma: characterization of a unique neoplasm by histology, immunohistochemistry, ultrastructure, and array-based comparative genomic hybridization. Archives of Pathology and Laboratory Medicine 2010134 1063-1069. (https://doi.org/10.1043/2009-0167-CR.1)

35 Grote A, Kovacs A, Clusmann H, Becker AJ \& Niehusmann P. Incidental pituicytoma after accidental head trauma - case report and review of literature. Clinical Neuropathology 201029 127-133. (https://doi.org/10.5414/npp29127)

36 Furtado SV, Ghosal N, Venkatesh PK, Gupta K \& Hegde AS. Diagnostic and clinical implications of pituicytoma. Journal of Clinical Neuroscience 201017 938-943. (https://doi.org/10.1016/j.jocn.2009.09.047)

37 Zhi L, Yang L, Quan H \& Bai-ning L. Pituicytoma presenting with atypical histological features. Pathology 200941 505-509. (https:// doi.org/10.1080/00313020903041119)

38 Wolfe SQ, Bruce J \& Morcos JJ. Pituicytoma: case report. Neurosurgery 200863 E173-E174. (https://doi.org/10.1227/01. NEU.0000335084.93093.C8)

39 Thiryayi WA, Gnanalingham KK, Reid H, Heald A \& Kearney T. Pituicytoma: a misdiagnosed benign tumour of the posterior pituitary. British Journal of Neurosurgery 200721 47-48. (https://doi. org/10.1080/02688690701218375)

40 Benveniste RJ, Purohit D \& Byun H. Pituicytoma presenting with spontaneous hemorrhage. Pituitary 20069 53-58. (https://doi. org/10.1007/s11102-006-8070-5)

41 Nakasu Y, Nakasu S, Saito A, Horiguchi S \& Kameya T. Pituicytoma. Two case reports. Neurologia Medico-Chirurgica 200646 152-156. (https://doi.org/10.2176/nmc.46.152)

42 Chen KT. Crush cytology of pituicytoma. Diagnostic Cytopathology 200533 255-257. (https://doi.org/10.1002/dc.20352)

43 Shah B, Lipper MH, Laws ER, Lopes MB \& Spellman MJ. Posterior pituitary astrocytoma: a rare tumor of the neurohypophysis: a case report. American Journal of Neuroradiology 200526 1858-1861.

44 Kowalski RJ, Prayson RA \& Mayberg MR. Pituicytoma. Annals of Diagnostic Pathology 20048 290-294. (https://doi.org/10.1016/j. anndiagpath.2004.07.006)

45 Ulm AJ, Yachnis AT, Brat DJ \& Rhoton Jr AL. Pituicytoma: report of two cases and clues regarding histogenesis. Neurosurgery 200454 753-758. (https://doi.org/10.1227/01.neu.0000108983.50966.b7)

46 Figarella-Branger D, Dufour H, Fernandez C, Bouvier-Labit C, Grisoli F \& Pellissier JF. Pituicytomas, a mis-diagnosed benign tumor of the neurohypophysis: report of three cases. Acta Neuropathologica 2002104 313-319. (https://doi.org/10.1007/s00401-002-0557-1)

47 Uesaka T, Miyazono M, Nishio S \& Iwaki T. Astrocytoma of the pituitary gland (pituicytoma): case report. Neuroradiology 200244 123-125. (https://doi.org/10.1007/s002340100654)

48 Brat DJ, Scheithauer BW, Staugaitis SM, Holtzman RN, Morgello S \& Burger PC. Pituicytoma: a distinctive low-grade glioma of the neurohypophysis. American Journal of Surgical Pathology 200024 362-368. (https://doi.org/10.1097/00000478-200003000-00004) 
49 Rossi ML, Bevan JS, Esiri MM, Hughes JT \& Adams CB. Pituicytoma (pilocytic astrocytoma): case report. Journal of Neurosurgery $1987 \mathbf{6 7}$ 768-772. (https://doi.org/10.3171/jns.1987.67.5.0768)

50 Kloub O, Perry A, Tu PH, Lipper M \& Lopes MB. Spindle cell oncocytoma of the adenohypophysis: report of two recurrent cases. American Journal of Surgical Pathology 200529 247-253. (https://doi. org/10.1097/01.pas.0000147400.87767.f6)

51 Borota OC, Scheithauer BW, Fougner SL, Hald JK, Ramm-Pettersen J \& Bollerslev J. Spindle cell oncocytoma of the adenohypophysis: report of a case with marked cellular atypia and recurrence despite adjuvant treatment. Clinical Neuropathology 200928 91-95. (https:// doi.org/10.5414/npp28091)

52 Coire CI, Horvath E, Smyth HS \& Kovacs K. Rapidly recurring folliculostellate cell tumor of the adenohypophysis with the morphology of a spindle cell oncocytoma: case report with electron microscopic studies. Clinical Neuropathology 200928 303-308. (https://doi.org/10.5414/npp28303)

53 Matyja E, Maksymowicz M, Grajkowska W, Olszewski W, Zieliński G $\&$ Bonicki W. Spindle cell oncocytoma of the adenohypophysis - a clinicopathological and ultrastructural study of two cases. Folia Neuropathologica 201048 175-184.

54 Borges MT, Lillehei KO \& Kleinschmidt-DeMasters BK. Spindle cell oncocytoma with late recurrence and unique neuroimaging characteristics due to recurrent subclinical intratumoral bleeding. Journal of Neuro-Oncology 2011101 145-154. (https://doi. org/10.1007/s11060-010-0229-2)

55 Demssie YN, Joseph J, Dawson T, Roberts G, de Carpentier J \& Howell S. Recurrent spindle cell oncocytoma of the pituitary, a case report and review of literature. Pituitary 201114 367-370. (https:// doi.org/10.1007/s11102-009-0170-6)

56 Ogiwara H, Dubner S, Shafizadeh S, Raizer J \& Chandler JP. Spindle cell oncocytoma of the pituitary and pituicytoma: two tumors mimicking pituitary adenoma. Surgical Neurology International 20112 116. (https://doi.org/10.4103/2152-7806.83932)

57 Fujisawa H, Tohma Y, Muramatsu N, Kida S, Kaizaki Y \& Tamamura H. Spindle cell oncocytoma of the adenohypophysis with marked hypervascularity. Case report. Neurologia Medico-Chirurgica 201252 594-598. (https://doi.org/10.2176/nmc.52.594)

58 Yoshimoto T, Takahashi-Fujigasaki J, Inoshita N, Fukuhara N, Nishioka H \& Yamada S. TTF-1-positive oncocytic sellar tumor with follicle formation/ependymal differentiation: non-adenomatous tumor capable of two different interpretations as a pituicytoma or a spindle cell oncocytoma. Brain Tumor Pathology 201532 221-227. (https://doi.org/10.1007/s10014-015-0219-3)

59 Manoranjan B, Koziarz A, Kameda-Smith MM \& Provias JP. Multiple recurrences require long-term follow-up in patients diagnosed with spindle cell oncocytoma of the sella turcica. Journal of Clinical Neuroscience 201743 134-146. (https://doi.org/10.1016/j. jocn.2017.05.017)

60 Sali A, Epari S, Tampi C \& Goel A. Spindle cell oncocytoma of adenohypophysis: review of literature and report of another recurrent case. Neuropathology 201737 535-543. (https://doi. org/10.1111/neup.12393)

61 Witte HM, Riecke A, Saeger W, Hackenbroch C, Mathieu R, Mauer UM \& Schulz C. Spindle cell oncocytoma of the neurohypophysis with metastasis to the sphenoparietal sinus and immunohistochemical negativity for S100 and epithelial membrane antigen (EMA). British Journal of Neurosurgery 201825 1-6. (https:// doi.org/10.1080/02688697.2018.1533107)

62 Larsen AM, Cote DJ, Zaidi HA, Bi WL, Schmitt PJ, Iorgulescu JB, Miller MB, Smith TR, Lopes MB, Jane JA, et al. Spindle cell oncocytoma of the pituitary gland. Journal of Neurosurgery $2018 \mathbf{1 3 1}$ 517-525. (https://doi.org/10.3171/2018.4.JNS18211)

63 Kong X, Li D, Kong Y \& Zhong D. Malignant adenohypophysis spindle cell oncocytoma with repeating recurrences and a high
Ki-67 index. Medicine 201796 e5657. (https://doi.org/10.1097/ MD.0000000000005657)

64 Vajtai I, Sahli R \& Kappeler A. Spindle cell oncocytoma of the adenohypophysis: report of a case with a 16-year follow-up. Pathology, Research and Practice 2006202 745-750. (https://doi. org/10.1016/j.prp.2006.05.008)

65 Singh G, Agarwal S, Chand Sharma MC, Suri V, Sarkar C, Garg A \& Kale SS. Spindle cell oncocytoma of the adenohypophysis: report of a rare case and review of literature. Clinical Neurology and Neurosurgery 2012114 267-271. (https://doi.org/10.1016/j.clineuro.2011.10.014)

66 Sollfrank L, Lettmaier S, Erdmann M \& Uslu U. Panniculitis under successful targeted inhibition of the MAPK/ERK signaling pathway in a patient with BRAF V600E-mutated spindle cell oncocytoma of the pituitary gland. Anticancer Research 201939 3955-3959. (https://doi. org/10.21873/anticanres.13549)

67 Oushy S, Graffeo CS, Perry A, Stafford SL, Link MJ \& Pollock BE. Single-fraction stereotactic radiosurgery for spindle cell oncocytoma: preliminary experience and systematic review of the literature. Journal of Neuro-Oncology 2019144 325-332. (https://doi. org/10.1007/s11060-019-03231-x)

68 Yavropoulou MP, Tsoli M, Barkas K, Kaltsas G \& Grossman A. The natural history and treatment of non-functioning pituitary adenomas (non-functioning PitNETs). Endocrine-Related Cancer 2020 27 R375-R390. (https://doi.org/10.1530/ERC-20-0136)

69 Levy MJ, Robertson IJ, Khalk N, Vitello S, Reddy N, Bhake R \& Howlett TA. Long-term follow-up of a large prospective cohort of patients with nonfunctioning pituitary adenomas: the outcome of a conservative management policy. Clinical Endocrinology 201889 354-359. (https://doi.org/10.1111/cen.13791)

70 Brochier S, Galland F, Kujas M, Parker F, Gaillard S, Raftopoulos C, Young J, Alexopoulou O, Maiter D \& Chanson P. Factors predicting relapse of nonfunctioning pituitary macroadenomas after neurosurgery: a study of 142 patients. European Journal of Endocrinology 2010163 193-200. (https://doi.org/10.1530/EJE-100255)

71 Covington MF, Chin SS \& Osborn AG. Pituicytoma, spindle cell oncocytoma, and granular cell tumor: clarification and meta-analysis of the world literature since 1893. American Journal of Neuroradiology 201132 2067-2072. (https://doi.org/10.3174/ajnr.A2717)

72 Scothorne CM. A glioma of the posterior lobe of the pituitary gland Journal of Pathology and Bacteriology 195569 109-112. (https://doi. org/10.1002/path.1700690115)

73 Roncaroli F, Scheithauer BW, Cenacchi G, Horvath E, Kovacs K, Lloyd RV, Abell-Aleff P, Santi M \& Yates AJ. Spindle cell oncocytoma of the adenohypophysis: a tumor of folliculostellate cells? American Journal of Surgical Pathology 200226 1048-1055. (https://doi. org/10.1097/00000478-200208000-00010)

74 Lee EB, Tihan T, Scheithauer BW, Zhang PJ \& Gonatas NK. Thyroid transcription factor 1 expression in sellar tumors: a histogenetic marker? Journal of Neuropathology and Experimental Neurology 200968 482-488. (https://doi.org/10.1097/NEN.0b013e3181a13fca)

75 Cykowski MD, Takei H, Baskin DS, Rivera AL \& Powell SZ. Epithelial and organ-related marker expression in pituitary adenomas. Neuropathology 201636 354-364. (https://doi.org/10.1111/ neup.12284)

76 Ahmed AK, Dawood HY, Cote DJ, Bale TA, De Girolami U, Laws ER \& Smith TR. Surgical resection of granular cell tumor of the sellar region: three indications. Pituitary 201922 633-639. (https://doi. org/10.1007/s11102-019-00999-z)

77 Loh JA \& Verbalis JG. Diabetes insipidus as a complication after pituitary surgery. Nature Clinical Practice: Endocrinology and Metabolism 20073 489-494. (https://doi.org/10.1038/ ncpendmet0513)

78 Hammoud DA, Munter FM, Brat DJ \& Pomper MG. Magnetic resonance imaging features of pituicytomas: analysis of 10 cases. https://ec.bioscientifica.com https://doi.org/10.1530/EC-20-0621 (c) 2021 The authors Published by Bioscientifica Ltd

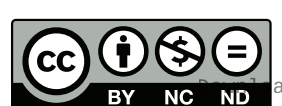

This work is licensed under a Creative Commons Attribution-NonCommercial-NoDerivatives 4.0 International License ifica com at $04 / 26 / 2023$ 08:10:35AM 
Journal of Computer Assisted Tomography 201034 757-761. (https:// doi.org/10.1097/RCT.0b013e3181e289c0)

79 Al Malki MH, Ahmad MM, Brema I, Al Dahmani KM, Pervez N, Al-Dandan S, Al Obaid A \& Beshyah SA. Contemporary management of clinically non-functioning pituitary adenomas: a clinical review. Clinical Medicine Insights: Endocrinology and Diabetes 202013 1179551420932921. (https://doi. org/10.1177/1179551420932921)

80 Greenman Y, Ouaknine G, Veshchev I, Reider-Groswasser II, Segev Y \& Stern N. Postoperative surveillance of clinically nonfunctioning pituitary macroadenomas: markers of tumour quiescence and regrowth. Clinical Endocrinology 200358 763-769. (https://doi. org/10.1046/j.1365-2265.2003.01784.x)

81 Vuong HG, Nguyen TPX, Pham N \& Dunn IF. Risk factors for tumor recurrence and progression of spindle cell oncocytoma of the pituitary gland: a systematic review and pooled analysis. Pituitary 2020 [epub]. (https://doi.org/10.1007/s11102-020-01110-7)

82 Dawoud FM, Naylor RM, Giannini C, Swanson AA, Meyer FB \& Uhm JH. TTF-1 positive posterior pituitary tumor: limitations of current treatment and potential new hope in BRAF V600E mutation variants. Clinical Neurology and Neurosurgery 2020196106059. (https://doi.org/10.1016/j.clineuro.2020.106059)

Received in final form 20 December 2020

Accepted 11 March 2021

Accepted Manuscript published online 12 March 2021 (c) 2021 The authors Published by Bioscientifica Ltd
This work is licensed under a Creative Commons Attribution-NonCommercial-NoDerivatives 4.0 Internationab dicense ifica.com at 04/26/2023 08:10:35AM 